HORTICULTURE

\title{
Quality of Rose Flowers in Different Types of Cultivation
}

\section{Komal* and Binoo Sehgal}

Department of Family Resource Management, Chaudhary Charan Singh Haryana Agricultural University, Hisar, Haryana, India "Corresponding author: kmlchauhan04@gmail.com (ORCID ID: 0000-0003-1522-9177)

\begin{abstract}
Floriculture is an essential branch of Horticulture concerned about growing and cultivating the flowers, foliage plants, and their marketing. It also deals with the production of planting materials through seedling, cutting, budding, and grafting. Polyhouse is a technology for flowers and vegetable cultivation through which farmers can get high and quality production and benefits. So, a study was planned for finding the quality of rose flowers in open cultivation and different polyhouses. The research was carried out in two different types of polyhouses and an open area. It was found that all the environment parameters, i.e., light, temperature, humidity, and $\mathrm{CO}_{2}$, were significantly higher in NVPH type of polyhouse compared to AISNH and open cultivation. Except for the diameter of rose flowers, all the other parameters of quality of flowers i.e., color, the height of flowers, a diameter of flowers and spikes etc., were higher in NVPH and AISNH than in the open cultivation.
\end{abstract}

\section{HIGHLIGHTS}

(0 Significant differences were found among all the environmental parameters, i.e. light, temperature, humidity, and $\mathrm{CO}_{2}$ level, in different cultivation units.

( Except diameter of rose flowers, all the quality parameters were higher in roses grown NVPH type of polyhouse.

Keywords: Anti Insect Shade net House, Environment, Flowers, Natural Ventilated Polyhouse, Rose, etc.

India is an agricultural country, and its history goes back to thousands of years. It is one of the most important sectors of the Indian economy. Even after several decades of independence, the majority of the rural population depends on agriculture for their livelihoods. Agriculture has several branches, and floriculture is one of them, which is concerned about the cultivation of flowers, foliage plants, and their marketing. The importance and potential of floriculture is unlimited and rising. According to apeda 2018 (a), production during 2015-16 was estimated to be 16,59,000 tonnes of loose flowers and $4,84,000$ tonnes of cut flowers. India has exported $20703.46 \mathrm{mt}$ of flowers to all over the world for a value of $₹ 507.31$ crores in the year of 2017-18. English roses were mostly grown in polyhouses for export purposes (Apeda 2018 (b)). Besides rose, other flowers like gerbera, lilium, and carnation were also produced for both domestic market and export purposes. Since the demand for cut flowers is increasing, protected cultivation in the polyhouse is the best alternative because it helps in providing suitable ecological conditions for the best and maximum production of flowers. Polyhouse is made of glass or plastic film. It allows only solar radiation to pass through but traps the thermal radiation which is emitted by the plants inside the polyhouse and also controls the temperature, humidity, and the intensity of light suitable for the production of flowers (Slathia 2018). It helps reduce the adverse effect of the environment, such as high/low humidity and temperature and gives

How to cite this article: Komal and Sehgal, B. 2021. Quality of Rose Flowers in Different Types of Cultivation. IJAEB, 14(03): 411-416.

Source of Support: None; Conflict of Interest: None $\infty$ 
improved quality and more quantity of flowers, and also protects the plants against incidence of pests and diseases. Demand for polyhouse farming in floriculture is increasing in the agriculture market. In india, the future of polyhouses is bright as we can see a changing trend towards tropical flowers. Wadkar et al. (2006) reported that profit of cutflowers production under the controlled climate was highest in orchid and lowest in rose.

Keeping the above facts in mind, the present study was planned with the objectives:

1. To assess the working conditions in open areas and different polyhouses.

2. To compare the quality and quantity of flowers grown in open areas and in different polyhouses.

\section{MATERIALS AND METHODS}

A methodology was set to achieve the planned objectives.

Locale of study: A list of farmers having floricultural units was prepared with the help of DHOs of Haryana state. Hisar, Panipat, and Sonepat districts of Haryana state were selected randomly from the prepared list.

Selection of flower and type of cultivation: English Rose was selected randomly among all the flowers grown by the farmers in all the cultivation units. From the prepared list of farmers having different types of flower cultivation units, one open cultivation and two different types of polyhouses (Natural Ventilated Polyhouse (NVPH) and Anti Insect Shade Net House (AISNH) were selected randomly as the sample of the study.

Tools and techniques: For the working conditions, environmental parameters (light, temperature, $\mathrm{CO}_{2}$ level, and humidity) and different facilities, i.e., electricity, water, first aid, transportation, etc. were taken. The light was measured by the lux meter, the temperature was measured by the thermometer, $\mathrm{CO}_{2}$ was measured by the Air quality monitor, and the hygrometer measured humidity. An observation sheet was prepared for the environmental parameters, and an interview schedule was developed to determine the working conditions in open cultivation and polyhouses.

The quality of flowers, such as color, shape, texture, and overall appearance, was judged with experts' help. It was also judged based on length of the stem, the diameter of flower, the diameter of stem, height of flower, size of flower etc. All these parameters were measured with the help of callipers. An observation sheet was also prepared. Quantity of flowers was measured by counting the number of sticks of flowers produced per unit area $\left(1000 \mathrm{~m}^{2}\right)$ and as per the response by the grower. Data were collected through the personal interview method.

Data Analysis: Percentage, mean, standard deviation, and ANOVA were calculated to draw meaningful inferences. Frequency and percentage were calculated for a general profile of farmers. Mean, SD determine the critical difference between, and ANOVA was calculated to determine the critical difference between the environmental parameters of open cultivation, AISNH, and NVPH. As per requirement, percent of difference of increase or decrease, average and ranks were calculated for measuring the quality of flowers. For the number of flowers, the total production of flowers was recorded by noting the number of sticks/spikes of flowers grown/unit area.

\section{RESULTS AND DISCUSSION}

Results are discussed under the following heads:

General profile of the farmers: Table 1 shows that 66.67 percent of farmers belonged to the $41-45$ years of age group, were post-graduate, having monthly income $₹ 40,001-50,000$ and were working with the collaboration of the DHOs.

Table 1: General profile of farmers working in three cultivation units

\begin{tabular}{llc}
\hline Sl. No. & Variables & Percentage \\
\hline $\mathbf{1}$ & Age (years) & \\
& 41-50 years & 66.67 \\
& 51-60 years & 33.33 \\
\hline $\mathbf{2}$ & Education & \\
& High School & 33.33 \\
& Post graduate & 66.67 \\
\hline $\mathbf{3}$ & Income/month & \\
& ₹ 20,000 - ₹ 30,000 & 33.33 \\
& ₹ 40,001 - ₹ 50,000 & 66.67 \\
\hline $\mathbf{4}$ & Collaboration with organisation \\
& DHOs & 66.67 \\
& KVKs & 33.33 \\
\hline
\end{tabular}



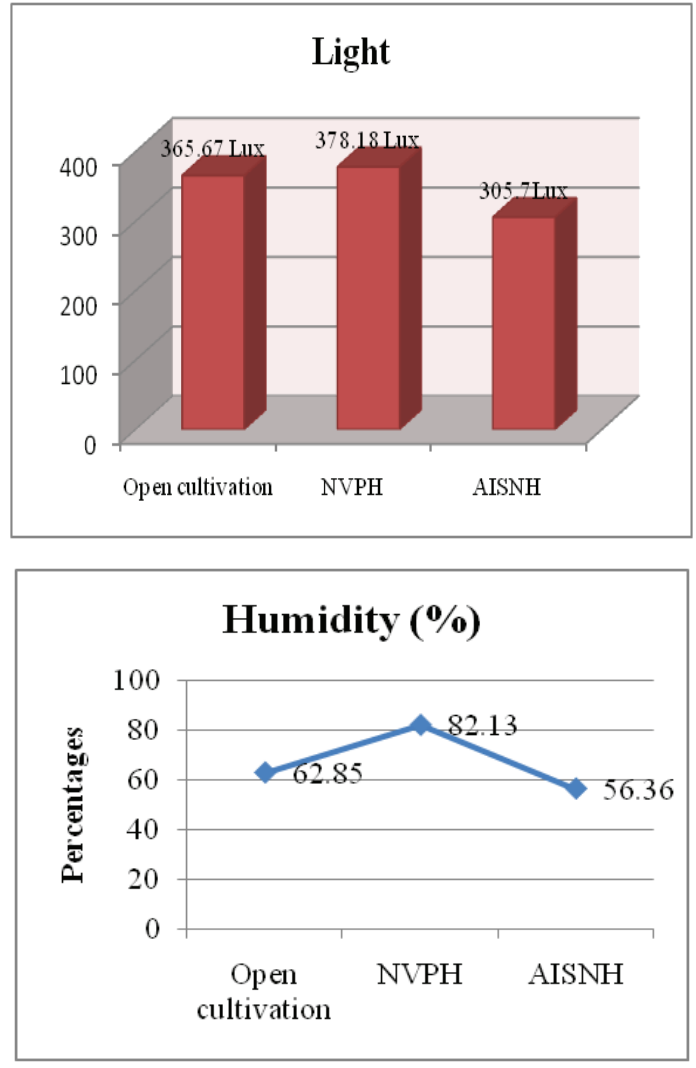
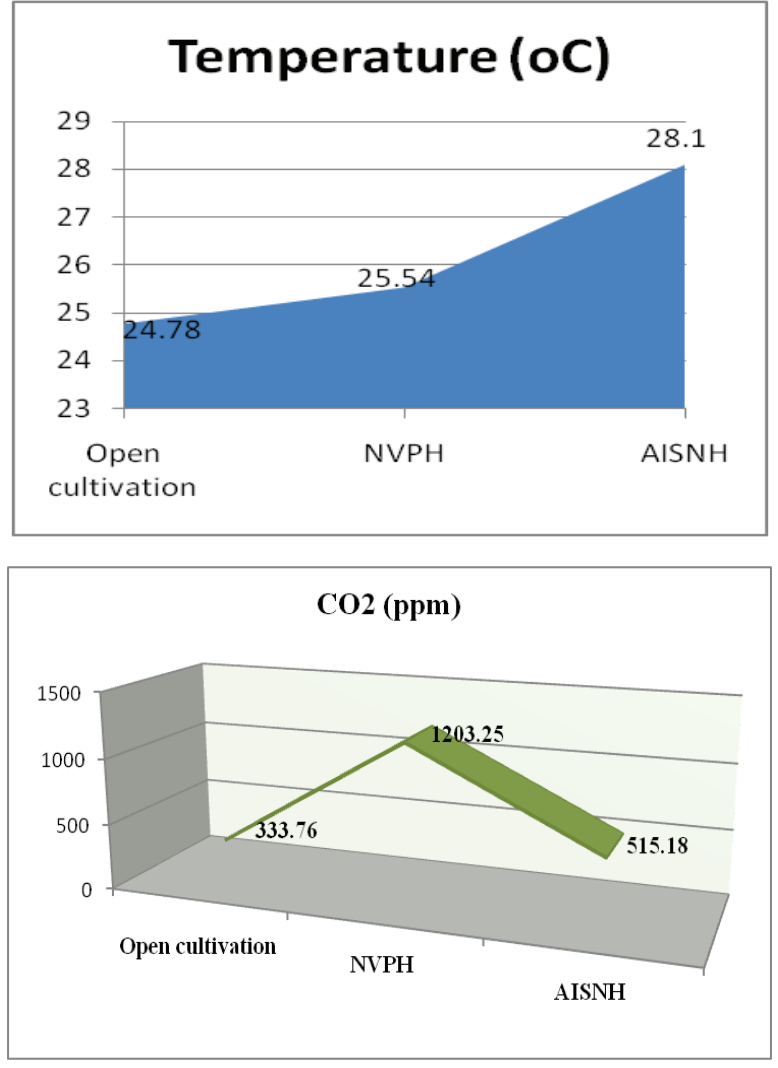

Fig. 1: Environmental conditions in different types of polyhouses of Rose Flowers

Environmental conditions in an open area and different types of polyhouses: Fig. 1 unfolds the environmental parameters including light, temperature, humidity, and $\mathrm{CO}_{2}$ in different types of cultivation. Maximum light (378.18 lux) was found in NVPH type of polyhouse, followed by open cultivation, i.e., $365.67 \mathrm{lux}$, and AISNH with 305.70 lux. The highest temperature $\left(28.10^{\circ} \mathrm{C}\right)$ was observed in AISNH types of polyhouse, followed by NVPH $\left(25.54^{\circ} \mathrm{C}\right)$ and lowest in open cultivation $\left(24.78^{\circ} \mathrm{C}\right)$. Singh et al. (2012) also found that $3.5^{\circ} \mathrm{C}$ more temperature was recorded inside the net houses. The highest humidity $(82.13 \%)$ was found in NVPH, followed by open cultivation $(62.85 \%)$ and lowest in 56.36 percent in AISNH type of polyhouse. Maximum $\mathrm{CO}_{2}$ level was found in NVPH (1203.25 ppm), followed by AISNH (515.18 ppm) and the lowest level of $\mathrm{CO}_{2}$ was found in open cultivation (333.76 ppm).

\section{Comparison of environmental parameters of three} types of cultivation units: Table 2 demonstrates the significant difference among environmental parameters in different types of cultivation units. It was observed that light in NVPH i.e. 372.18 lux, was significantly higher than open cultivation and AISNH (305.70 lux) with CD 21.29. Temperature was higher in AISNH $\left(28.09^{\circ} \mathrm{C}\right)$, and humidity was significantly higher in NVPH (82.13\%) with CD 5.92. $\mathrm{CO}_{2}$ level was found to be significantly higher in NVPH (1203.25 ppm) followed by AISNH (515.18 ppm) and open area (333.76 ppm) with CD 79.11.

Table 2: Comparison of environmental parameters of three types of cultivation of rose flowers

\begin{tabular}{llllll}
\hline $\begin{array}{l}\text { S1. } \\
\text { No. }\end{array}$ & Variables & $\begin{array}{l}\text { Open } \\
\text { area }\end{array}$ & AISNH NVPH & CD \\
\hline 1 & Light (Lux) & $365.68^{\mathrm{b}}$ & $305.70^{\mathrm{ac}}$ & $372.18^{\mathrm{b}}$ & 21.29 \\
2 & Temperature $\left({ }^{\circ} \mathrm{C}\right)$ & $24.78^{\mathrm{bc}}$ & $28.09^{\mathrm{a}}$ & $25.54^{\mathrm{b}}$ & 01.49 \\
3 & Humidity $(\%)$ & $62.85^{\mathrm{c}}$ & $56.36^{\mathrm{c}}$ & $82.13^{\mathrm{ab}}$ & 05.92 \\
4 & $\mathrm{CO}_{2}(\mathrm{ppm})$ & $333.76^{\mathrm{c}}$ & $515.18^{\mathrm{c}}$ & $1203.25^{\mathrm{ab}}$ & 79.11 \\
\hline
\end{tabular}

Facilities available at the workplace of the floricultural units

Table 3 shows the facilities available at the workplace i.e. transportation, irrigation, electricity, packaging material, and storage. It was clear from the table that most farmers had canal facilities for irrigation, electricity supply, and packaging material. The 
majority of farmers $(66.67 \%)$ were using their personal vehicle and were using tube-well. It was also clear that only 33.33 percent of farmers had the storage facilities to store the flowers.

Table 3: Facilities available at the workplace of the floricultural units $(\mathrm{n}=3)$

\begin{tabular}{lll}
\hline $\begin{array}{l}\text { S1. } \\
\text { No. }\end{array}$ & Facilities & Percentage \\
\hline 1 & Transportation & \\
& Personal vehicle & 66.67 \\
& Rental vehicle & 33.33 \\
\hline 2 & Irrigation & \\
& Tube-well & 66.67 \\
& Canal water & 100 \\
\hline 3 & Electricity & 100 \\
\hline 4 & Packaging material & 100 \\
\hline 5 & Storage infrastructure & 33.33 \\
\hline
\end{tabular}

\section{Quality of rose flowers in different types of floricultural units}

Table 4 presents the quality of rose flowers i.e., the diameter of flowers, the height of flowers, diameter of the stick, length of sticks etc., in different types of floricultural units. Only diameter $(6.70 \mathrm{~cm})$ of rose flowers was higher in open cultivation than any other type of floricultural units followed by NVPH $(5.9 \mathrm{~cm})$ and AISNH $(5.80 \mathrm{~cm})$. The maximum height of flowers $(12.95 \mathrm{~cm})$ was found in NVPH, followed by AISNH $(11.68 \mathrm{~cm})$ and open cultivation (10.41 $\mathrm{cm})$. The diameter of stick/spike was maximum in flowers grown in NVPH $(0.95 \mathrm{~cm})$, followed by AISNH $(0.90 \mathrm{~cm})$ and open cultivation $(0.69$ $\mathrm{cm})$. Length of stick/spike was highest in flowers grown in NVPH $(93.98 \mathrm{~cm})$, followed by AISNH $(91.44 \mathrm{~cm})$ and open cultivation $(86.36 \mathrm{~cm}) . \mathrm{NVPH}$ type of polyhouse had the controlling system of environmental parameters, making the environment suitable for the growth of flowers.

Maximum number of petals were found in rose flowers grown in NVPH (94) polyhouse, followed by AISNH (80) and open cultivation (70). Maximum shelf life of rose flowers was found in flowers grown in NVPH i.e., nine days, followed by a shelf-life of eight days in the case of flowers grown in open cultivation and AISNH (5 days).

Fig. 2 clearly shows that the quality of rose flowers was much better in both the polyhouses than the open cultivation in terms of the color of flowers, texture of flowers, hardness of stick, and overall appearance of rose flowers.

\section{Quality of rose flowers on the basis of observation by experts in different types of cultivation units}

Table 5 unfolds the quality of rose flowers in different types of floricultural units based on judgment of experts. It was found that mean scores of the color of flowers, the texture of flowers, hardness of spikes, and overall appearance of flowers were found maximum in NVPH type of polyhouse. The highest color score of rose flowers was 5.00 grown in NVPH, followed by AISNH (4.10) and open area (3.70). The texture of flowers scored highest (4.40) in NVPH, followed by AISNH (4.36) and open area (3.90). The hardness of sticks/spikes scored $5.00(\mathrm{NVPH})$, followed by AISNH (4.70), and open area (4.50). Overall appearance of flowers scored 4.70 (NVPH), followed by AISNH (4.30) and open area (3.90). In totality, NVPH scored highest i.e., 19.10 and ranked I, followed by AISNH (17.54)

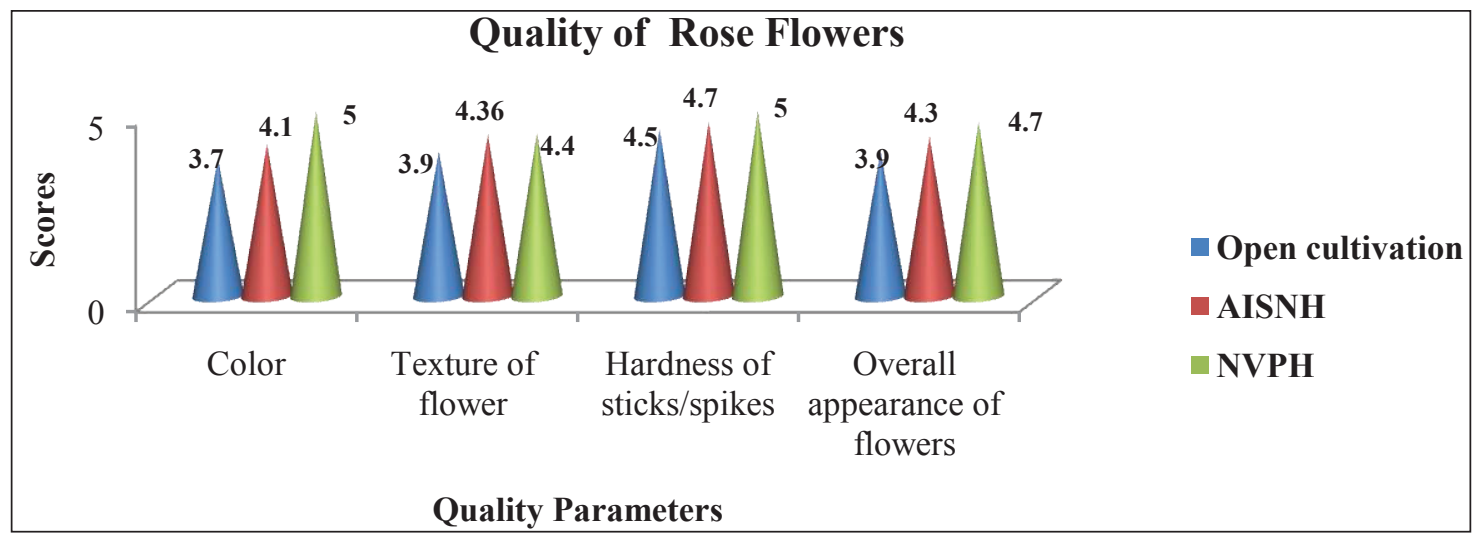

Fig. 2: Mean scores of quality of rose flowers 
Table 4: Comparison of quality of Rose flowers in polyhouses and open cultivation $(n=3)$

\begin{tabular}{lllllll}
\hline \multirow{2}{*}{$\begin{array}{l}\text { Sl. } \\
\text { No. }\end{array}$} & Parameters & Open cultivation & \multicolumn{3}{c}{ AISNH } & NVPH \\
\cline { 3 - 6 } & Value & Value & $\begin{array}{l}\text { \% difference with } \\
\text { open cultivation }\end{array}$ & Value & $\begin{array}{c}\text { \% difference with } \\
\text { open cultivation }\end{array}$ \\
\hline 1 & Diameter of flowers (cm) & 06.70 & 05.80 & -14.4 & 5.9 & -11.94 \\
2 & Height of flowers (cm) & 10.41 & 11.68 & +12.20 & 12.95 & +24.40 \\
3 & Diameter of sticks (cm) & 0.69 & 0.90 & +30.43 & .95 & +37.68 \\
4 & Length of sticks (cm) & 86.36 & 91.44 & +05.88 & 93.98 & +08.82 \\
5 & Number of petals & 70 & 80 & +14.29 & 94 & +34.26 \\
6 & Shelf-life of flowers (days) & 8 & 5 & +37.50 & 9 & +12.50 \\
\hline
\end{tabular}

Table 5: Quality of rose flowers on the basis of observation by experts in different types of cultivation units

\begin{tabular}{lllllll}
\hline \multirow{2}{*}{ S1. No. } & Parameters & Open cultivation & \multicolumn{2}{c}{ AISNH } & \multicolumn{2}{c}{ NVPH } \\
\cline { 3 - 7 } & & Value & Value & \% difference & Value & \% difference \\
\hline 1 & Color & 3.70 & 4.10 & +10.81 & 5.00 & +35.14 \\
2 & Texture of flowers & 3.90 & 4.40 & +12.80 & 4.40 & +12.82 \\
3 & Hardness of sticks & 4.50 & 4.70 & +4.44 & 5.00 & +11.11 \\
4 & Overall appearance of flowers & 3.90 & 4.30 & +10.26 & 4.70 & +20.51 \\
\hline
\end{tabular}

ranked II, and open cultivation (16.00) ranked III. It was also concluded that the production was higher in both the polyhouses than the open cultivation.

\section{Production of Rose flowers per unit area in different floricultural units}

The selected area for rose cultivation was $1000 \mathrm{~m}^{2}$. Total plants grown by the farmers were 3,500 plants in NVPH, WIT and AISNH and 3,000 plants in the open area. Maximum production, i.e. 95,833 sticks/ spikes, was found in NVPH type of polyhouse, followed by AISNH (77,000 sticks/spikes) and in the open area (42,500 sticks/spikes).

Table 6: Production of Rose flowers per unit area in different floricultural units

\begin{tabular}{lllll}
\hline $\begin{array}{l}\text { Sl. } \\
\text { No. }\end{array}$ & Variable & $\begin{array}{l}\text { Open } \\
\text { area }\end{array}$ & AISNH & NVPH \\
\hline 1 & Area & $1000 \mathrm{~m}^{2}$ & $1000 \mathrm{~m}^{2}$ & $1000 \mathrm{~m}^{2}$ \\
2 & $\begin{array}{l}\text { Total plants (in } \\
\text { numbers) }\end{array}$ & 3000 & 3500 & 3500 \\
3 & $\begin{array}{l}\text { Production (sticks/ } \\
\text { spikes in number) }\end{array}$ & 42500 & 77000 & 95833 \\
4 & Total bunches & 4250 & 7700 & 9583 \\
\hline
\end{tabular}

So, it was concluded that the production of rose flowers was highest in both the poly houses compared to the open area. Tilekar (2002) and Toppo (2018) also reported that poly houses in controlled conditions gave 4-8 times more production than open cultivation. Makadia et al. (2012) also supported these results and revealed that the cost-benefit ratio was found economically beneficial i.e., 2.15 .

\section{CONCLUSION}

Floriculture is one of the most growing and exportoriented sectors of agriculture. The government of India has already taken so many initiatives to promote floriculture, and the promotion of poly houses is one of them. It is concluded that the quality of roses grown in both polyhouses was of good quality than the open cultivation. Production of roses was higher in poly houses than the open cultivation because of controlled and suitable environmental conditions.

\section{REFERENCES}

APEDA 2018(a). http://www.apeda.gov.in/apedawebsite/ SubHead_Products/Floriculture.htm Last Access 4th April, 21.

APEDA2018(b).https://apeda.gov.in/apedawebsite/six_head_ product/floriculture.htm Last Access 12 ${ }^{\text {th }}$ February, 21.

Chawla, S.L., Patil, S., Ahlawat, T.R. and Agnihotri R. 2016. Present Status, Constraints and Future Potential of Floriculture in India. Commercial Horticulture, pp. 29-38.

Makadia, J., Patel, K. and Ahir, N. 2012. Economics of Production of Rose Cut Flower in South Gujarat. Int. Res. J. Agric. Econ. Stat., 3(1): 111-114. 
Komal and Sehgal

Singh, J., Nangare, D., Kumar, P. and Bhatnagar, R. 2012. Protected cultivation for organic vegetable production. Central Institute of Post-harvest Engineering \& Technology (CIPHET) PAU, Punjab.

Slathia, D., Nisa, M.U., Reshi, M. D.T. and Hussain, S. 2018. Protected Cultivation of Ornamentals. G.J.B.B., 7(2): 1-10.

Tilekar, S.N. 2002. Impact of Polyhouse Technology on Production and Profitability of Roses Cut Flowers. J. Maharashtra Econ. Soc.
Toppo, A. 2018. What are the Benefits of Polyhouse Cultivation. Https://Krishijagran.Com/Agripedia/WhatAre-The-Benefits-of-Polyhouse-Cultivation/12December, 2018 4:09 Pm Ist. Last Access: 12 ${ }^{\text {th }}$ June 2021.

Vahoniya, D., Ranjan, S., Panigrahy, Patel, D. and Patel, J. 2018. Status of Floriculture in India: With Special Focus to Marketing. Int. J. Pure App. Bio Sci., 6(2): 1434-1438.

Wadkar, S., Bagade, S. and Veerkar, P. 2006. A Study on the Economics of Cut flower Production under Polyhouse. Agric. Econ. Res. Rev., 19: 214. 